\title{
UWAGI O TEISTYCZNEJ INTERPRETACJI ZASADY ANTROPICZNEJ
}

\begin{abstract}
Streszczenie. Artykuł jest próbą odpowiedzi na pytanie, jaką wartość dla teologicznej argumentacji za istnieniem Boga ma zasada antropiczna. Mówi ona o subtelnym „dostrojeniu” praw przyrody i parametrów kosmologicznych, bez którego we wszechświecie nie mógłby pojawić się człowiek. Wszechświat wydaje się zatem istnieć dla określonego celu, jakim jest „wyprodukowanie” rozumnego obserwatora. Ze względu na swój teleologiczny charakter zasada antropiczna jest podatna na interpretację teologiczną, w której zakłada się, że to Bóg powołuje do istnienia wszechświat przygotowany dla człowieka. W tym ujęciu Stwórca jawi się jako projektant wszechświata, ale Jego projekt dotyczy tu tylko praw przyrody - z tej racji interpretacja ta różni się zasadniczo od tzw. teorii inteligentnego projektu. W artykule uzasadniono tezę, że zasada antropiczna jest ciekawym argumentem - ale nie naukowym dowodem - za racjonalnością religijnej wiary w Boga, który jest stwórcą wszechświata.
\end{abstract}

Słowa kluczowe: zasada antropiczna, kosmiczne koincydencje, subtelne dostrojenie, „dowód” kosmologiczny

1. Antropiczne wyjaśnienia kosmicznych koincydencji. 2. Pomiędzy teleologią i teologią. 3. Czy wszechświat jest zaprojektowany? 4. Interpretacja teistyczna a naturalistyczne wyjaśnienia kosmicznych koincydencji.

Jeden $\mathrm{z}$ bardziej istotnych argumentów analizowanych $\mathrm{w}$ ramach teologii naturalnej ${ }^{1}$, która na gruncie czysto filozoficznym poszukuje racji przemawiających za istnieniem Boga, ma związek z uporządkowaniem, harmonią i pięknem świata przyrody. Istotę tego argumentu dobrze oddaje intuicja zawarta w słowach Księgi Mądrości: „Z wielkości i piękna stworzeń poznaje się przez podobieństwo ich Stwórcę" (Mdr 13,5). Historia teologii i filozofii dostarcza wielu in-

1 Pod tym określeniem będę w niniejszym artykule rozumiał dyscyplinę filozoficzną zajmującą się istnieniem i naturą Boga - dyscyplinę określaną również mianem teologii filozoficznej, teologii racjonalnej, filozofii Boga albo teodycei. 
teresujących przykładów wykorzystania tej intuicji w argumentacji dotyczącej objawienia naturalnego albo kosmologicznych „dowodów” na istnienie Boga, w których określone własności świata przyrody traktuje się jako przesłankę rozumowania prowadzącego do wniosku o obecności Stwórcy. Ze względu na interdyscyplinarny charakter tej problematyki, dyskusja nad wartością i zasadnością takiej argumentacji została w czasach nowożytnych w istotny sposób ukierunkowana rozwojem nauk empirycznych. Nauki te odsłoniły bowiem nieznane wcześniej aspekty uporządkowania i racjonalności świata przyrody, która przejawia się w działaniu matematycznych praw opisywanych odpowiednimi teoriami fizycznymi. Dla teologii wszelkie przejawy tej racjonalności stają się filozoficznym argumentem przemawiającym za stwórczą obecnością Boga, który powołuje do istnienia cały wszechświat i kieruje jego rozwojem za pośrednictwem praw przyrody.

Współczesną dyscypliną nauk empirycznych, która najpełniej wydaje się potwierdzać spójność tej narracji, jest kosmologia relatywistyczna. Nauka ta ukazuje niezwykle subtelną zależność zachodzącą pomiędzy istnieniem człowieka a wartościami stałych przyrody i parametrów kosmologicznych, które zdecydowały o tym, że we wszechświecie mogła rozpocząć się ewolucja życia biologicznego i że w wyniku tej ewolucji pojawił się rozumny obserwator. Ujmująca tę zależność zasada antropiczna, która jest współczesną koncepcją z pogranicza nauk empirycznych i filozofii, dostarcza interesującego argumentu dla teologicznej dyskusji nad kosmologicznymi „dowodami” na istnienie Boga. Jaka jest wartość tego argumentu i w jakim zakresie można go wykorzystać w tej dyskusji? Niniejszy artykuł jest próbą znalezienia odpowiedzi na to pytanie.

\section{ANTROPICZNE WYJAŚNIENIA KOSMICZNYCH KOINCYDENCJI}

Zależności zachodzące pomiędzy faktem istnienia istot rozumnych oraz określonymi własnościami wszechświata, które to zaistnienie 
umożliwiły, określa się mianem kosmicznych lub antropicznych koincydencji². W tym kontekście mówi się również o precyzyjnym albo subtelnym „dostrojeniu” ( fine tuning) ${ }^{3}$, które dotyczy parametrów - są nimi np. masy cząstek elementarnych albo różnego rodzaju stałe (stała grawitacji, stała Plancka itp.) - decydujących o tym, że wszechświat spełnia warunki umożliwiające ewolucję życia biologicznego. Wyraźne powiązanie tych dwóch faktów - pierwszym jest obecność we wszechświecie rozumnego obserwatora, drugim to, że własności wszechświata tę obecność rzeczywiście umożliwiają - dokonało się w latach 70. ubiegłego wieku. Brandon Carter po raz pierwszy użył wtedy określenia „Zasada antropiczna”4, które odtąd miało się stać swego rodzaju etykietą problematyki dotyczącej wspomnianych zależności. W sensie ścisłym jednak zależności te nie dotyczą obecności we wszechświecie samego człowieka - a właśnie to sugeruje określenie „zasada antropiczna” - ale warunków koniecznych do ewolucji życia. Na oznaczenie tego zagadnienia proponuje się w związku z tym również inne określenia, takie jak np. „zasada biofiliczna”, „zasada węglowa”, „zasada planetarna”, „zasada galaktyczna”, „zasada psychocentryczna”, „zasada poznawalności” itp. Ale historia tego zagadnienia miała swój początek znacznie wcześniej - zanim jeszcze pojawiły się tego typu określenia ${ }^{5}$. Składają się na tę historię

2 Por. np. J. Turek, Kosmiczne koincydencje. Proponowane wyjaśnienia, Lublin 2014; Z. Klimek, Koincydencje dużych liczb kosmologii i mikrofizyki, Postępy Astronomii 24(1976)4, 223-233; J. Gribbin, M. Rees, Kosmiczne zbiegi okoliczności. Ciemna materia, ludzkość i antropiczna kosmologia, tłum. z ang. P. Amsterdamski, Warszawa 1996.

3 Por. np. S. Coleman, Fine-Tuning and Probability: Does the Universe Require Explanation?, Sophia 40(2001)1, 7-15; J.J. Davis, The Design Argument, Cosmic "Fine-Tuning" and the Athropic Principle, Philosophy of Religion 22(1987), 139-150; J. Leslie, Przejawy delikatnego dostrojenia, tłum. z ang. W. Maciejewski, Zagadnienia Filozoficzne w Nauce 16(1994), 27-62.

4 B. Carter, Large Number Coincidences and the Anthropic Principle in Cosmology, w: Confrontation of Cosmological Theories with Observational Data, red. M.S. Longair, Dordrecht 1974, 291-298.

5 Na temat tej historii por. np. J.D. Barrow, F. Tipler, The Anthropic Cosmological Principle, New York 1986, 219-287; J. Turek, Kosmiczne koincydencje, dz. cyt., 104-119. 
epizody związane $z$ odkryciami dokonywanymi przez uczonych, którzy zauważali zagadkowe zbieżności dotyczące $\mathrm{z}$ jednej strony stałych przyrody i różnego rodzaju parametrów kosmologicznych, z drugiej zaś - obecności we wszechświecie istot rozumnych.

Jedno z pierwszych tego typu spostrzeżeń dotyczyło tzw. koincydencji wielkich liczb i zostało dokonane przez Arthura S. Eddingtona i Paul A.M. Diraca, którzy w latach 30. XX wieku zauważyli, że istnieje ciekawy związek pomiędzy mechaniką kwantową i kosmologią: stosunek wielkości charakterystycznych dla świata kwantowego (np. siły wiążącej elektron $z$ jądrem atomowym) i dla świata makroskopowego (np. siły oddziaływania grawitacyjnego) jest stały i w przybliżeniu zawsze równy liczbie $10^{40 .}{ }^{6} \mathrm{Z}$ przeprowadzonych obliczeń wynikało, że to właśnie ta liczba określa np. ilość barionów w obserwowalnym wszechświecie albo obecny wiek wszechświata wyrażony w tzw. naturalnych jednostkach czasu? ${ }^{7}$ Czy taka zbieżność jest czysto przypadkowa, czy też wynika z jakichś głębszych uwarunkowań? $Z$ czasem zaczęło przybywać argumentów przemawiających za słusznością tej drugiej możliwości, przy czym w argumentach tych coraz częściej zaczęły pojawiać się nawiązania do obecności człowieka we wszechświecie. Żeby na arenie dziejów mógł pojawić się człowiek, najpierw musiała rozpocząć się biologiczna ewolucja życia. Ponieważ zaś ta forma życia oparta jest na węglu - autorem tego rozumowania jest Robert Dicke - człowiek będący wynikiem ewolucji biologicznej nie mógł pojawić się we wszechświecie, zanim ten pierwiastek nie został wyprodukowany $\mathrm{w}_{\text {gwiazdach }}{ }^{8}$. $\mathrm{Z}$ kolei do podtrzymywania życia potrzebne jest odpowiednie źródło energii - takie jak stabilna gwiazda o średniej masie - i dlatego rozumny

6 Zob. A.S. Eddington, Preliminary note on the masses of the electron, the proton and the universe, Proceedings of the Cambridge Philosophical Society 27(1931), 15-19; P.A.M. Dirac, Cosmological constants, Nature 139(1937), 323.

7 Naturalna jednostka czasu (równa 10-23 s) to interwał czasu, w jakim światło pokonuje odległość równą średnicy jądra atomowego.

8 R.H. Dicke, Dirac's Cosmology and Mach's Principle, Nature 192(1961), 440-441. 
obserwator nie będzie mógł istnieć w odległej przyszłości wszechświata, gdy już wszystkie gwiazdy zgasną. Życie biologiczne oparte na węglu mogło zatem pojawić się tylko w stosunkowo krótkim okresie historii wszechświata - określonym liczbą $10^{40}$ naturalnych jednostek czasu - w którym panują warunki sprzyjające jego ewolucji.

Bez obecności węgla i odpowiedniej gwiazdy stanowiącej stabilne źródło energii życie biologiczne nie mogłoby się rozwinąć. Nie są to jednak jedyne warunki konieczne do spełnienia, by we wszechświecie mógł pojawić się rozumny obserwator. Szybko okazało się, że lista takich warunków (określonych przez konkretne wartości stałych przyrody i różnego rodzaju parametrów kosmologicznych) jest bardzo długa i że - co było najbardziej zagadkowe - w obecnym wszechświecie każdy z nich jest dokładnie spełniony. „Szczęśliwe zbiegi okoliczności”, które umożliwiły ewolucję życia, dotyczą najpierw takich parametrów, jak wiek wszechświata, jego wielkość (promień) i masa (ilość zawartej w nim materii) ${ }^{9}$. Ścisła zależność zachodząca pomiędzy tymi wielkościami w zasadniczy sposób decyduje o tym, że taka ewolucja mogła się rozpocząć. Do budowy organizmów biologicznych oprócz węgla potrzebne są bowiem również inne pierwiastki (tlen, wodór, azot, siarka, fosfor itd.), które powstają w masywnych gwiazdach. Aby jednak takie gwiazdy mogły się pojawić, od Wielkiego Wybuchu musiało upłynąć kilka miliardów lat. Równie długi okres czasu potrzebny był do tego, by z materii „wyprodukowanej” w gwiazdach i rozrzuconej w przestrzeni kosmicznej powstały planety (takie jak Ziemia) i stabilne gwiazdy kolejnej generacji (takie jak Słońce). Nic więc dziwnego, że ekspandujący przez tak długi czas wszechświat musi mieć ogromne rozmiary przestrzenne, i musi zawierać znaczne ilości materii. Co istotne, ilość

9 Por. np. B. Carter, The anthropic principle and its implications for biological evolution, Philosophical Transactions of the Royal Society A310(1983), 347-363; J. Turek, Dlaczego wszechświat jest tak duży, jak jest?, w: Filozoficzne i naukowo-przyrodnicze elementy obrazu świata, red. G. Bugajak, A. Latawiec, t. 3, Warszawa 2001, 132-143. 
tej materii jest bardzo precyzyjnie określona: gdyby bowiem masa wszechświata była zbyt mała, siła grawitacji nie zdołałaby odpowiednio spowolnić pierwotnego tempa ekspansji czasoprzestrzeni (a to uniemożliwiłoby powstanie wielkoskalowych struktur, takich jak galaktyki, i w konsekwencji - układów planetarnych zbudowanych wokół stabilnych gwiazd); gdyby zaś była zbyt duża, grawitacja bardzo szybko powstrzymałaby ekspansję i doprowadziła do kolapsu (co znowu przekreśliłoby możliwość powstania galaktyk, w których może rozpocząć się ewolucja życia biologicznego) ${ }^{10}$. W obecnym wszechświecie galaktyki zdołały się utworzyć, co oznacza, że stosunek siły związanej z ekspansją czasoprzestrzeni do hamującej siły oddziaływania grawitacyjnego materii jest określony w taki sposób, iż wszechświat może uniknąć dwóch skrajności uniemożliwiających ewolucję życia. Niezwykłą subtelność tego „dostrojenia” ujawniają obliczenia, z których wynika, że gdyby tuż po Wielkim Wybuchu tempo ekspansji wszechświata wzrosło zaledwie o $0,1 \%$, to obecna jego wartość byłaby tysiące razy większa od obserwowanej; gdyby zaś zmalało o $0,1 \%$, to wszechświat bardzo szybko uległby grawitacyjnemu kolapsowi. W obydwu przypadkach nie mogłyby powstać galaktyki, i nie mogłoby rozwinąć się życie ${ }^{11}$.

Argumentów za tym, że wszechświat rzeczywiście „balansuje na ostrzu noża”, i że to „balansowanie” umożliwia pojawienie się rozumnego obserwatora, jest znacznie więcej. Dotyczą one np. koincydencji związanych z tzw. parametrem gęstości $\Omega^{12}$ (w obecnym wszechświecie jest on niemal dokładnie równy jedności, a to oznacza, że tuż po Wielkim Wybuchu jego wartość musiała być

10 Por. J.D. Barrow, F. Tipler, dz. cyt., 384-385.

11 Zob. R.H. Dicke, Gravitation and the Universe, Philadelphia 1970, 62.

12 Jest on definiowany przez stosunek średniej gęstości materii do tzw. gęstości krytycznej, która wystarcza do zatrzymania gwałtownej ekspansji czasoprzestrzeni, ale zarazem jest zbyt mała do rozpoczęcia kontrakcji. 
określona z nieprawdopodobną precyzją: $\left.1-10^{-60}<\Omega<1+10^{-60}\right)^{13}$ albo z wielkością pierwotnych fluktuacji gęstości materii, z których później mogły wyłonić się galaktyki i inne struktury wielkoskalowe (pomiary anizotropii promieniowania reliktowego potwierdzają słuszność teoretycznych przewidywań, z których wynika, że wielkość tych fluktuacji musiała być precyzyjnie określona bardzo wąskim przedziałem $\left.10^{-5}<\mathrm{d} \rho / \rho<10^{-4}\right)^{14}$. W opracowaniach dotyczących zasady antropicznej wskazuje się również na wiele innych koincydencji, które umożliwiły ewolucję życia biologicznego. „Subtelne dostrojenie" dotyczy m.in. mas cząstek elementarnych, stabilności atomów, stosunku liczby fotonów do liczby barionów, asymetrii barionowej (nieznacznej nadwyżki materii nad antymaterią), wartości stałej kosmologicznej (która określa wpływ ciemnej energii na tempo ekspansji wszechświata), wielkości oddziaływań fundamentalnych (grawitacji, elektromagnetyzmu, oddziaływań jądrowych silnych i słabych), własności i lokalizacji gwiazd i planet oraz wielu innych zagadkowych „kosmicznych zbiegów okoliczności”15. Nawet najmniejsza zmiana warunków określonych przez tzw. swobodne parametry (są nimi np. masy cząstek i siły oddziaływań), które decydują o tych koincydencjach, uniemożliwiłaby rozwój życia biologicznego.

Istnieje przynajmniej kilka koncepcji, które w odmienny sposób wyjaśniają omówione koincydencje (o kilku z nich będzie mowa w dalszej części tego artykułu), natomiast sama zasada antropiczna wiąże ich obecność z pojawieniem się człowieka - rozumnego obserwatora wszechświata. Brandon Carter wyróżnił dwie odmienne, choć niewykluczające się, wersje tej zasady: słabą i mocną ${ }^{16}$. Słaba zasada antropiczna zawiera intuicję, którą już wcześniej - przed Carterem -

13 Por. B.J. Carr, On the Origin, Evolution and Purpose of the Physical Universe, Irish Astronomical Journal 15(1982)3, 244.

14 Por. J.D. Barrow, F.J. Tipler, dz. cyt., 417; J. Turek, Kosmiczne koincydencje, dz. cyt., 24-29.

15 Por. np. J. Leslie, art. cyt., 27-62; J. Turek, Kosmiczne koincydencje, dz. cyt., 13-85; P. Davies, Zasada antropiczna, Postępy Fizyki 37(1986)3, 215-249.

16 Zob. B. Carter, Anthropic Principle in Cosmology, arXiv:gr-qc/0606117 [dostęp: 19.01.2018]. 
wypowiadało wielu innych autorów: ponieważ we wszechświecie faktycznie pojawił się człowiek, to wszechświat nie może być jakikolwiek - musi umożliwiać zaistnienie rozumnego obserwatora. „To, co spodziewamy się zaobserwować - zauważa Carter - musi spełniać warunki do istnienia nas jako obserwatorów (...). Nasze położenie we wszechświecie jest w sposób konieczny uprzywilejowane w tym sensie, że powinno być zgodne z naszym istnieniem jako obserwatorów"17. Myśl Cartera można zinterpretować następująco: nie ma żadnej zagadki w tym, że życie rozwinęło się tu (w pobliżu stabilnej gwiazdy) i teraz (kilkanaście miliardów lat po Wielkim Wybuchu), bo w innych miejscach i innych okresach historii wszechświata rozwinąć się nie mogło. Ta sama okoliczność wyjaśnia to, dlaczego człowiek obserwuje dziś taki a nie inny wszechświat: życie nie mogło pojawić się wcześniej, i nie będzie mogło istnieć później, więc nic dziwnego, że obserwator nie ma dostępu do wcześniejszych i późniejszych okresów historii wszechświata.

Mocna zasada antropiczna w sposób o wiele bardziej radykalny wiąże obecność człowieka z własnościami wszechświata. W oryginalnym sformułowaniu Cartera zasada ta brzmi następująco: „wszechświat (a więc i podstawowe parametry, od których on zależy) musi być taki, ażeby dopuszczał zaistnienie obserwatorów na pewnym etapie swoich dziejów"18. Jak widać, różnica względem słabego sformułowania zasady antropicznej jest tu zasadnicza: wszechświat nie może - zgodnie z mocną wersją zasady - być nieprzyjazny człowiekowi, musi umożliwiać jego zaistnienie. „Nasze zwykłe istnienie jako rozumnych obserwatorów - wyjaśnia istotę tej wersji Carter - nakłada ograniczenia nie tylko na naszą sytuację, ale również na ogólne własności wszechświata, włączając w to wartości fundamentalnych

17 B. Carter, Large Number Coincidences and the Anthropic Principle in Cosmology, art. cyt., 291, 293.

18 Tamże, 294. 
parametrów"19. Koniecznościowy charakter mocnej zasady antropicznej (wszechświat musi być taki...) decyduje o tym, że łatwo nadać jej interpretację teleologiczną, uznając, że wszechświat istnieje dla konkretnego celu, jakim jest „wyprodukowanie” istot rozumnych. Nic dziwnego, że większość autorów właśnie w taki sposób rozumie tę wersję zasady antropicznej ${ }^{20}$.

\section{POMIĘDZY TELEOLOGIĄ I TEOLOGIĄ}

Czy idea celowości wszechświata rzeczywiście znajduje swoje potwierdzenie w mocnej zasadzie antropicznej? Jak wiadomo, wyjaśnienia teleologiczne zostały na progu czasów nowożytnych wyeliminowane z nauk empirycznych, i dlatego nauki te poszukują w świecie przyrody związków przyczynowo-skutkowych, a nie celowościowych. Nic dziwnego, że dane obserwacyjne dotyczące kosmicznych koincydencji i „subtelnych dostrojeń” bezpośrednio nie potwierdzają tego, iż wszechświat istnieje dla określonego celu. Mocną zasadę antropiczną, która zdaje się dostarczać argumentów za tym, że tak właśnie jest, traktuje się w związku z tym raczej jako koncepcję filozoficzną, a nie ściśle naukową - choć zdania są tu podzielone i nie brakuje autorów opowiadających się za tym, że mocna zasada antropiczna to nauka, a nie filozofia ${ }^{21}$. Co istotne, teleologiczny wydźwięk tej zasady decyduje o tym, że staje się ona również bardzo podatna na interpretację teologiczną: wyjaśnienie głoszące, że wszechświat musi być taki, by umożliwić ewolucję życia prowadzącą do pojawienia się $\mathrm{w}$ nim rozumnego obserwatora, przypomina bowiem argumentacje opartą na religijnej wierze w to, że to sam Bóg powołał do istnienia wszechświat specjalnie „przygotowany” dla człowieka.

19 B. Carter, The anthropic principle and its implications for biological evolution, art. cyt., 351.

20 Por. J. Życiński, The Anthropic Principle and the Teleological Interpretation of Nature, Reviev of Metaphysics 41(1987), 317-333.

21 Por. J. Turek, Kosmiczne koincydencje, dz. cyt., 189-209. 
Dyskutując nad istotą i merytoryczną wartością wyjaśnień teleologicznych, nie należy jednak zapominać o tym, że nieobecność takich wyjaśnień w naukach empirycznych wynika przede wszystkim z metodologicznych założeń leżących u podstaw tych nauk, a nie $\mathrm{z}$ jakichś głębszych powodów, które w sposób jednoznaczny decydowałyby o wyższości wyjaśnień przyczynowych nad celowościowymi. Metoda nauk przyrodniczych została „zaprojektowana” do wykrywania i opisywania związków przyczynowo-skutkowych, a nie do dostarczania wyjaśnień celowościowych. Nic więc dziwnego, że nauki empiryczne „zauważają” związki kauzalne zachodzące pomiędzy zdarzeniami i obiektami świata przyrody i systematycznie pomijają wszystko to, co dla tych związków nie jest ważne. Jeśli wyjaśnienia teleologiczne rzeczywiście zostały wyeliminowane z nauk ścisłych, to właśnie w takim sensie: procedura badawcza nakazuje naukowcom koncentrować się na tym, co jest oddziaływaniem kauzalnym i „nie zauważać” tego, co nim nie jest. Tak określona reguła metody - systematyczne pomijanie aspektów nie mających związku $\mathrm{z}$ relacjami przyczynowo-skutkowymi - nie zmienia jednak samego świata przyrody, który w rzeczywistości podlega różnego rodzaju ukierunkowaniom, choć $\mathrm{z}$ racji metodologicznych nauki empiryczne nie mogą tych ukierunkowań dostrzec.

Najbardziej wyraźny przykład takiego ukierunkowania można zauważyć w świecie organizmów roślinnych i zwierzęcych, które zachowują się tak, jak gdyby realizowały jasno określone cele. Roślina rozsiewająca nasiona, $\mathrm{z}$ których wyrosną potomne rośliny, albo ptak budujący gniazdo, w którym złoży jaja i wychowa pisklęta - to najprostsze przykłady tego typu zachowań. Nawet jeśli nauki biologiczne wyjaśniają te zachowania jedynie w kategoriach przyczyn i skutków, to jednak ich celowościowy charakter jest oczywisty. Również sama ewolucja biologiczna, choć oparta na przypadkowych mutacjach, 
wydaje się podlegać wyraźnemu ukierunkowaniu ${ }^{22}$. Wynika ono przede wszystkim z działania mechanizmu doboru naturalnego, który jest procesem twórczym, prowadzącym do nieustannego wzrostu złożoności organizmów żywych, zdolnych do rozwoju i ciągłego przystosowywania się do zmieniających się warunków środowiska ${ }^{23}$. Nic dziwnego, że nie brakuje dziś opinii przemawiających za tym, iż choć biologia nie dowodzi istnienia wyraźnego celu ewolucji, to jednak tego celu jednoznacznie nie wyklucza - co z kolei otwiera pole dla różnego rodzaju interpretacji filozoficznych dotyczących tego zagadnienia ${ }^{24}$.

Zasada antropiczna wydaje się potwierdzać słuszność tego samego wniosku, przy czym wspomniane ukierunkowanie nie dotyczy w tym przypadku jedynie ewolucji biologicznej, ale globalnej ewolucji całego wszechświata. Jeśli rzeczywiście jest tak, że nawet najmniejsza zmiana parametrów kosmologicznych i stałych przyrody wykluczyłaby możliwość pojawienia się życia na Ziemi i jeśli mimo wszystko parametry i stałe tę możliwość dopuszczają dzięki „subtelnym dostrojeniom", to ten wyjątkowo szczęśliwy zbieg okoliczności można uznać właśnie za przejaw globalnego ukierunkowania wszechświata. Choć nauki empiryczne ze wspomnianych wcześniej racji bezpośrednio tego ukierunkowania nie potwierdzają, to jednak dostarczają mocnych argumentów za tym, że takie ukierunkowanie faktycznie istnieje. Co istotne, argumenty te wpisują się dobrze nie tylko w interpretację filozoficzną tego zagadnienia, ale również w teologiczną narrację dotyczącą celowego działania Boga, który powołuje

22 Por. S. Conway Morris, Life's Solution: Inevitable Humans in a Lonely Universe, Cambridge 2003.

23 Interesujące przykłady tego typu przystosowania podaje F.J. Ayala w książce Dar Karola Darwina dla nauki i teologii, tłum. z ang. P. Dawidowicz, Warszawa 2009, 55-57, 138-141.

24 Por. W.R. Stoeger, The Immanent Directionality of the Evolutionary Process, and Its Relationship to Theology, w: Evolutionary and Molecular Biology: Scientific Perspectives on Divine Action, red. R.J. Russell, W.R. Stoeger, F.J. Ayala, Vatican City State - Berkeley 1998, 184. 
do istnienia wszechświat "przygotowany” dla człowieka. Pozostając na płaszczyźnie wyjaśnień teologicznych, można bowiem uznać, że globalne ukierunkowanie wszechświata, o którym mówi mocna wersja zasady antropicznej, dostarcza ważnej racji przemawiającej za spójnością teizmu ewolucyjnego ${ }^{25}$. Zgodnie $\mathrm{z}$ tą koncepcją, stwórcze działanie Boga dokonuje się za pośrednictwem praw przyrody, które powodują nieustanny rozwój wszechświata, zachodzący na wszystkich poziomach uorganizowania materii, i w konsekwencji prowadzący do ewolucji życia i pojawienia się człowieka. Dane nauk empirycznych dotyczące kosmicznych koincydencji i ,subtelnych dostrojeń" stałych przyrody nie mogą być z oczywistych względów traktowane jako naukowe dowody na obecność celowego zamysłu Stwórcy powołującego do istnienia wszechświat, który ma być przyjaznym „mieszkaniem” dla człowieka. Wydają się one jednak wyraźnie sprzyjać właśnie takiej interpretacji i potwierdzać jej słusznośćc ${ }^{26}$.

Teleologiczna argumentacja za istnieniem Boga ma długą historię, w której niejednokrotnie pojawiała się w przeszłości pokusa apologetyki polegającej na „wypełnianiu” Stwórcą dziur w naukowej wiedzy o świecie (God of gaps $)^{27}$. Dziś nie ulega już wątpliwości, że taki sposób wyjaśniania niezrozumiałych aspektów świata przyrody jest błędem metodologicznym, który w rzeczywistości przynosi teologii więcej szkody niż pożytku. Rozwój nauk przyrodniczych bardzo często dostarcza bowiem naturalnego wyjaśnienia tego, co wcześniej tłumaczono bezpośrednim działaniem Stwórcy. „Hipoteza Boga” staje się w takim przypadku niepotrzebna, a argumentacja teleologiczna,

25 Por. np. J. Życiński, Bóg i ewolucja. Podstawowe pytania ewolucjonizmu chrześcijańskiego, Lublin 2002, 91-104; D. Edwards, Bóg ewolucji. Teologia trynitarna, tłum. z ang. Ł. Kwiatek, Kraków 2016, 70-85.

26 Por. G.F.R. Ellis, The Theology and the Anthropic Principle, w: Quantum Cosmology and the Laws of Nature: Scientific Perspectives on Divine Action, red. R.J. Russell, N.C. Murphy, Ch.J. Isham, Vatican City State - Berkeley 1996, 367-405.

27 Na temat argumentacji teleologicznej, por. np. T. Pabjan, Argument teleologiczny, w: Przewodnik po filozofii religii. Nurt analityczny, red. J. Salamon, Kraków 2016, 255-269. 
która w zamyśle apologety miała dowodzić istnienia Stwórcy, nie tylko traci jakąkolwiek siłę przekonywania, ale dodatkowo obraca się przeciwko temu, co rzekomo miała wykazywać. W kontekście dyskutowanego w tym artykule zagadnienia warto zauważyć, że globalne ukierunkowanie wszechświata, o którym mówi mocna zasada antropiczna, potraktowane jako argument za słusznością teizmu ewolucyjnego, nie jest narażone na ten sam zarzut. Kosmiczne koincydencje dotyczące „subtelnego dostrojenia” parametrów i stałych przyrody nie są bowiem „dziurami” w naukowej wiedzy o świecie. Nauki empiryczne po prostu stwierdzają prosty fakt: parametry i stałe przyrody są takie a nie inne. Nadając temu zagadnieniu interpretację teologiczną należy zatem uznać, że działanie Boga nie polega na nadzwyczajnych - sprzecznych z prawami przyrody - ingerencjach oznaczających „wypełnianie” tego, czego nauka nie jest w stanie wyjaśnić, ale jedynie na ustalaniu zestawu praw przyrody i konsekwentnym respektowaniu określonego w ten sposób porządku wszechświata ewoluującego zgodnie z tymi prawami ${ }^{28}$. Jak wiadomo, problem genezy praw przyrody jest zagadnieniem metanaukowym. Nie jest zatem metodologicznym błędem to, gdy poszukując jego wyjaśnienia na płaszczyźnie teologicznej, wskazuje się na Boga, który jest najgłębszym źródłem racjonalności wszechświata, przejawiającej się $\mathrm{w}$ działaniu matematycznych praw przyrody ${ }^{29}$.

\section{CZY WSZECHŚWIAT JEST ZAPROJEKTOWANY?}

Dla dyskusji nad możliwością wykorzystania zasady antropicznej w filozoficzno-teologicznej argumentacji za istnieniem Boga

28 Por. np. D. Edwards, Jak działa Bóg?, tłum. z ang. M. Chojnacki, Kraków 2013, 74-111; T. Pabjan, Anatomia konfliktu. Pomiędzy nowym ateizmem a teologią nauki, Kraków 2016, 115-142; R.J. Russell, Boże działanie w świecie, w: Stwórca - wszechświat - człowiek, red. M. Heller, T. Sierotowicz, t. I, Tarnów 2006, 91-104.

29 Por. J. Polkinghorne, Prawa natury i prawa fizyki, w: Stwórca - Wszechświat - człowiek, dz. cyt., 200-215; W.B. Drees, Czy istnieją dziury, w których działa Bóg?, w: tamże, 216-235. 
istotne jest to, w jaki sposób rozumie się ideę projektu, która zdaje się wynikać z mocnej wersji tej zasady. Jeśli wszechświat istnieje dla jasno określonego celu, jakim jest „wyprodukowanie” rozumnego obserwatora, to znaczy, że stałe przyrody i parametry kosmologiczne umożliwiające ewolucję życia biologicznego musiały zostać przez Stwórcę bardzo precyzyjnie dobrane. Trudną do wyobrażenia skalę tej precyzji dobrze oddaje znany argument Rogera Penrose'a, który obliczył, że prawdopodobieństwo tego, iż wszechświat wyłaniający się z początkowej osobliwości będzie przyjazny dla życia biologicznego, jest mniejsze niż 1 do $10^{10^{123}} 30$. Mówiąc o akcie stworzenia, można w związku z tym wyobrażać sobie Boga, który cienką igłą musi trafić w jeden nieskończenie mały punkt w ogromnej przestrzeni fazowej ${ }^{31}$. „Aby stworzyć wszechświat podobny do tego, w jakim żyjemy - zauważa Penrose - Stwórca musiałby trafić w absurdalnie małą komórkę w przestrzeni fazowej możliwych wszechświatów. Objętość takiej komórki jest $10^{10^{123}}$ razy mniejsza niż objętość całej przestrzeni fazowej"32. Jak widać, precyzja, z jaką zostały dobrane parametry wszechświata, który sprzyja życiu, jest ogromna. Nic dziwnego, że w tym kontekście w sposób nieomal naturalny pojawia się idea projektu: wszechświat sprzyja życiu, bo Stwórca specjalnie przygotował go - „zaprojektował” - dla człowieka.

Warto w tym miejscu zauważyć, że idea ta jest poniekąd podobna do innej koncepcji mówiącej o projekcie, która współcześnie zyskuje znaczną popularność $\mathrm{w}$ dyskusjach z pogranicza teologii

30 Zob. R. Penrose, Droga do rzeczywistości. Wyczerpujący przewodnik po prawach rzadzących wszechświatem, tłum. z ang. J. Przystawa, Warszawa 2006, 700, 732-734.

31 Przestrzeń fazowa jest abstrakcyjną przestrzenią matematyczną, w której każdy punkt oznacza jeden z możliwych stanów danego układu. W przykładzie analizowanym przez Penrose'a chodzi o przestrzeń fazową możliwych wszechświatów - każdy punkt takiej przestrzeni oznacza jedną z wszystkich możliwych konfiguracji stałych przyrody i warunków początkowych charakteryzujących jeden z możliwych wszechświatów.

32 R. Penrose, Makroświat, mikroświat i ludzki umysł, tłum. z ang. P. Amsterdamski, Warszawa 1997, 58. 
i nauk empirycznych, a mianowicie do tzw. teorii inteligentnego projektu (ID) ${ }^{33}$. Ta ostatnia teoria nie dotyczy projektu całego wszechświata, ale mówi o projekcie pewnych jego podstruktur, tzn. organizmów żywych. Jej zwolennicy sądzą, że współczesna teoria ewolucji nie wystarcza do pełnego wyjaśnienia subtelnej złożoności tych organizmów. Złożoność ta nie mogła - ich zdaniem - powstać na skutek działania doboru naturalnego i przypadkowych mutacji w materiale genetycznym i dlatego należy przyjąć, że organizmy są bezpośrednio projektowane przez Boga. Ze względu na chęć upodobnienia tej koncepcji do teorii ściśle naukowych, jej wyznawcy wolą w tym kontekście mówić o działaniu Inteligentnego Projektanta (a nie Boga), ale ich intencja jest w tym przypadku jasna: chodzi o zakwestionowanie wyjaśnień proponowanych przez teorię ewolucji i znalezienie naukowego „dowodu” na bezpośrednie działanie Stwórcy, projektującego żywe organizmy ${ }^{34}$.

Dla merytorycznej i metodologicznej oceny obydwu koncepcji, w których pojawia się idea projektu - pierwsza z nich dotyczy zasady antropicznej i „kosmicznego projektu”, druga teorii ID i „biologicznego projektu" 35 - istotne jest to, że w obydwu przypadkach projekt dokonuje się na zupełnie innym poziomie i dotyczy odmiennych

33 Argumenty zwolenników tej teorii można znaleźć m.in. w książkach: M.J. Behe, Darwin’s Black Box. The Biochemical Challenge to Evolution, New York 1996; W.A. Dembski, Intelligent Design: The Bridge Between Science and Theology, Downers Grove 1999. Historię tej koncepcji i jej merytoryczną ocenę przedstawia M. Heller w książce Filozofia przypadku. Kosmiczna fuga z preludium i codą, Kraków 2011, 131-186.

34 Sędzia John E. Jones prowadzący w Dover w roku 2005 sprawę dotyczącą teorii inteligentnego projektu (Kitzmiller vs. Dover Area School District) w następujący sposób uzasadnia werdykt wydany w tej sprawie: „Przytłaczające dowody przedstawione w procesie wskazują, iż ID jest poglądem religijnym, zwykłym kreacjonizmem występującym pod zmienionym szyldem, nie zaś teorią naukową. (...) ID nie jest nauką i nie może być uznany za uzasadnioną, akceptowaną teorię". http://bit.ly/spc55-1-p1 [dostęp: 19.01.2018].

35 Por. S.M. Barr, Fizyka współczesna a wiara w Boga, tłum. z ang. A. Molek, Wrocław 2005, 77-78. Rozróżniając te koncepcje, autor koncentruje się na analizie „struktur symetrycznych” występujących w świecie przyrody nieożywionej i „struktur organicznych” charakteryzujących żywe organizmy. 
aspektów świata przyrody. W pierwszym przypadku projekt dotyczy praw przyrody i subtelnie „zestrojonych ze sobą” warunków początkowych, od których rozpoczyna się ewolucja wszechświata; w drugim zaś przedmiotem projektu są szczegóły anatomiczne żywych organizmów, których rzekomo nie jest w stanie wyjaśnić syntetyczna teoria ewolucji. Funkcja projektanta jest zatem zupełnie inna w obydwu tych przypadkach: w pierwszym $z$ nich projektant jedynie określa zestaw przyjaznych życiu praw przyrody i nie występuje w charakterze jednej z przyczyn fizyko-chemicznych możliwych do zidentyfikowania przez nauki empiryczne; $w$ drugim narusza porządek określony przez te prawa, ingerując bezpośrednio w świat przyrody ożywionej, a jego „projektowanie” sprowadza się w rzeczywistości do działania jednej z przyczyn naturalnych, którą mogą odkrywać i badać nauki empiryczne. Metodologiczna ocena obydwu tych koncepcji musi być zatem różna. Jeśli chodzi o teorię ID, to rości sobie ona prawo do tego, by uchodzić za teorię naukową (obecność projektanta jest tu wykazywana na płaszczyźnie ściśle naukowej), ale zarazem nie respektuje podstawowych zasad metodologii nauk, wyjaśniając funkcjonowanie organizmów bezpośrednim działaniem nadprzyrodzonego projektanta ${ }^{36}$. Jest również obarczona ryzykiem teologicznego błędu „współczesnego manicheizmu”"37, polegającego na nieuzasadnionym wyłączaniu zdarzeń przypadkowych z całego arsenału środków, którymi może posługiwać się Stwórca powołujący do istnienia wszechświat podlegający ewolucji.

$\mathrm{Na}$ takie ryzyko nie jest wystawiona teologiczna interpretacja mocnej zasady antropicznej. Interpretacja ta nie jest bowiem koncepcją naukową (ale metanaukową), i dlatego nie jest w tym przypadku metodologicznym błędem wskazywanie na Stwórcę, który jedynie określa zestaw praw przyrody powodujący ewolucję wszechświata przyjaznego życiu i który nie narusza określonego przez

36 Por. T. Pabjan, Anatomia konfliktu, dz. cyt., 98-104.

37 Zob. M. Heller, dz. cyt., 141-147. 
siebie porządku nadprzyrodzonymi interwencjami w świat przyrody. Wcześniej była już mowa o tym, że problem natury i genezy praw przyrody nie może być rozstrzygany na płaszczyźnie nauk empirycznych, i dlatego dyskusja dotycząca tego zagadnienia musi mieć charakter metanaukowy. Pozostając na płaszczyźnie wyjaśnień filozoficzno-teologicznych, można bez naruszania zasad metodologicznych dostrzegać w Bogu ostateczne źródło racjonalności przejawiającej się w działaniu matematycznych praw przyrody, które umożliwiły pojawienie się we wszechświecie rozumnego obserwatora. Co istotne, nadawanie właśnie takiej interpretacji zasadzie antropicznej wpisuje się dobrze w wielowiekową tradycję teologicznej argumentacji, która w uporządkowaniu i harmonii świata przyrody dostrzegała zawsze ślad stwórczej obecności Boga ${ }^{38}$.

\section{INTERPRETACJA TEISTYCZNA A NATURALISTYCZNE WYJAŚNIENIA KOSMICZNYCH KOINCYDENCJI}

Teistyczne wyjaśnienia antropicznych koincydencji z oczywistych względów nie zamykają dyskusji nad interpretacją zasady antropicznej i nie wyczerpują zbioru możliwych odpowiedzi na pytanie o przyczynę „,kosmicznych zbiegów okoliczności”, które umożliwiły ewolucję życia we wszechświecie. Zbiór tych odpowiedzi jest bardzo obszerny i w znacznej mierze zdominowany przez propozycje mające związek z teoriami współczesnych nauk empirycznych. Nic dziwnego, że rozwiązanie teistyczne, wskazujące na Boga, który powołał do istnienia świat przyjazny dla człowieka, w wielu opracowaniach dotyczących zasady antropicznej jest marginalizowane albo nawet całkowicie pomijane. Co istotne, alternatywne propozycje wyjaśnień antropicznych koincydencji bardzo często motywowane są właśnie chęcią wykazania, że zagadkowe dostrojenie kosmicznych

38 Więcej na temat teologicznej interpretacji zasady antropicznej, por. J. Turek, Kosmiczne koincydencje, dz. cyt., 260-279. 
parametrów można wytłumaczyć bez odwoływania się do Stwórcy, który ustala zestaw praw przyrody sprzyjających ewolucji życia. Nie bez znaczenia jest również wspomniana wcześniej okoliczność dotycząca tego, że zasada antropiczna - zwłaszcza w mocnej wersji ma wydźwięk teleologiczny, a to ze zrozumiałych względów budzi podejrzliwość u wielu przedstawicieli nauk empirycznych. Poszukują oni w związku z tym rozwiązań, w których obecność kosmicznych koincydencji można byłoby wyjaśnić bez uwzględniania przyczyn celowościowych.

Dla zilustrowania stanu współczesnej dyskusji nad zasadą antropiczną warto w tym miejscu choćby krótko wspomnieć o kilku koncepcjach, które dostarczają naturalistycznego wyjaśnienia antropicznych koincydencji i które stanowią alternatywę dla stanowiska teistycznego. Przykładem takiej koncepcji jest tzw. teoria wielu światów, którą Hugh Everett zaproponował pierwotnie dla usunięcia interpretacyjnych trudności pojawiających się w mechanice kwantowej ${ }^{39}$. Każdy z możliwych wyników pomiaru, przewidywanych przez formalizm tej teorii, realizuje się - zgodnie z rozwiązaniem Everetta w osobnym wszechświecie. „Techniczne szczegóły” tej propozycji (np. mechanizm powstawania nowych światów w momencie pomiaru) mają związek z mechaniką kwantową, ale jej ogólna idea okazuje się dostarczać jednego z możliwych wyjaśnień kosmicznych koincydencji, które sprzyjają życiu. Jeśli założyć, że realnie istnieje wiele, lub nawet nieskończenie wiele, wszechświatów różniących się między sobą konfiguracją praw przyrody i parametrów kosmologicznych, to antropiczne koincydencje występujące w jednym z tych wszechświatów przestają być zagadką: we wszystkich innych światach konfiguracja praw i stałych przyrody wyklucza możliwość ewolucji życia i dlatego tam nie pojawił się rozumny obserwator wyrażający swoje zdumienie subtelnym dostrojeniem parametrów odpowiedzialnych

$39 \mathrm{H}$. Everett, 'Relative state' formulation of quantum mechanics, Reviews of Modern Physics $29(1957) 3,454-462$. 
za jego zaistnienie. Pojawił się on za to w „naszym” wszechświecie, bo tylko tutaj ta konfiguracja na to zezwoliła.

Istotnym zarzutem formułowanym pod adresem teorii wielu światów jest jej zasadnicza nieweryfikowalność; nie bez znaczenia jest również gigantyczny „bagaż metafizyczny”, którym to rozwiązanie jest obarczone ${ }^{40}$. Podobna słabość charakteryzuje również inną propozycję dostarczającą naturalistycznego wyjaśnienia kosmicznych koincydencji, a mianowicie koncepcję wszechświata partycypacyjnego, której autorem jest John A. Wheeler ${ }^{41}$. Nawiązuje ona do filozoficznych idei Berkeleya, który głosił, że istnieje tylko to, co jest postrzegane (esse est percipi), i do jednej z podstawowych regul mechaniki kwantowej, zgodnie $\mathrm{z}$ którą akt obserwacji decyduje o tym, że obiekt kwantowy uzyskuje realność, której przed momentem pomiaru był pozbawiony. Tę samą intuicję - zdaniem Whellera - należy odnieść do całego wszechświata, który istnieje ( $\mathrm{z}$ całą swoją przeszłą historią) dlatego, że obecnie jest obserwowany przez człowieka. Jest to wszechświat „uczestniczący” (partycypacyjny) w tym sensie, że obserwator, decydujący o realnym zaistnieniu całego kosmosu, sam partycypuje w aktualizacji wszechświata jako całości ${ }^{42}$. Ponieważ zaś obserwator jest organizmem biologicznym i zarazem istotą rozumną, wszechświat, który istnieje dzięki jego obserwacji, jest uporządkowany i sprzyjający życiu.

Jak widać, obydwie przywołane powyżej koncepcje - teoria wielu światów i idea wszechświata partycypacyjnego - oparte są na bardzo mocnych założeniach filozoficznych. Co ciekawe, założenia takie pojawiają się również w znakomitej większości innych, „naturalnych”

40 Por. T. Pabjan, Teoria wielu światów - nauka czy filozofia?, Filozofia Nauki 63-64(2008), 141-154.

41 Por. J.A. Wheeler, Genesis and Observership, w: Foundational Problem in Special Sciences, red. R.E. Butts, J. Hintikka, Dordrecht 1977, 3-33.

42 Por. E.E. Harris, Cosmos and Anthropos. A Philosophical Interpretation of the Anthropic Cosmological Principle, New Jersey - London 1991, 7; P. Davies, The Accidental Universe, Cambridge 1993, 122. 
wyjaśnień, dyskutowanych współcześnie w kontekście problemu kosmicznych koincydencji. Wielu uczonych ${ }^{43}$ opowiada się dziś za tym, że w problemie tym w rzeczywistości nie kryje się żadna tajemnica: wszechświat nie ma żadnego celu, a w jego istnieniu nie należy się dopatrywać żadnego sensu ani projektu - jest to wszechświat absurdalny, który jedynie przez czysty przypadek umożliwił ewolucję życia. Stawianie pytań o przyczynę tego „umożliwienia” jest w związku z tym równie nieuzasadnione jak poszukiwanie wyjaśnienia tego, że na loterii przypadkiem wygrało się szczęśliwy los. Za jeszcze innym rozwiązaniem problemu antropicznych koincydencji opowiadają się ci, którzy sądzą, że wszechświat jest niepowtarzalny - w tym sensie, że z nieznanych przyczyn (być może poszukiwana od lat „teoria wszystkiego" 44 pozwoli kiedyś te przyczyny poznać) istnieje tylko jeden możliwy, wewnętrznie spójny, zestaw stałych i praw przyrody, którym odpowiada tylko jeden możliwy wszechświat. To, że sprzyja on życiu, byłoby w tym przypadku jedynie konieczną konsekwencją (brak odpowiedniej teorii unifikującej fizykę nie pozwala tej konieczności na razie zrozumieć) tego, że opisujący jego funkcjonowanie matematyczny formalizm po prostu nie dopuszczałby innej możliwości.

Uznanie, że wszechświat, w którym żyjemy, jest absurdalny i że nie ma żadnej tajemnicy w tym, iż obowiązujące w nim prawa przyrody umożliwiły ewolucję życia, jest stosunkowo najłatwiejszym sposobem „wyjaśnienia” antropicznych koincydencji. Trudno jednak oprzeć się wrażeniu, że w rzeczywistości jest to raczej ucieczka przed problemem, a nie próba jego rozwiązania. Poza tym - jeśli wszechświat jest absurdalny, to zupełnie niezrozumiałe stają się sukcesy współczesnej nauki, która tak skutecznie odkrywa jego tajemnice.

43 Paul Davies sądzi, że „jest to prawdopodobnie najszerzej reprezentowane wśród uczonych stanowisko" dotyczące zasady antropicznej; zob. P. Davies, Kosmiczna wygrana. Dlaczego wszechświat sprzyja życiu?, tłum. z ang. B. Bieniok, E.L. Łokas, Warszawa 2008, 284.

44 Pod tym określeniem fizycy rozumieją najczęściej teorię, która pozwoli połączyć ze sobą mechanikę kwantową i ogólną teorię względności, i która dostarczy spójnego opisu wszystkich zjawisk fizycznych we wszechświecie. 
Jeśli zaś wszechświat jest niepowtarzalny i jeśli z jakichś powodów prawa przyrody nie mogą być inne, niż są, i muszą pozwalać na ewolucję życia, to tego typu „wyjaśnienie” - pomijając to, że jest wysoce hipotetyczne i że odwołuje się do fizycznej teorii, której jeszcze nie ma-niewiele różni się od argumentacji wynikającej z mocnej zasady antropicznej.

Arbitralne, mocne założenia - bardzo często o wydźwięku filozoficznym (a nawet więcej: metafizycznym) - to wysoka cena, jaką trzeba zapłacić za znalezienie „naturalnego” wyjaśnienia antropicznych koincydencji. Widać to również dobrze w przypadku przywołanej uprzednio teorii wielu światów i koncepcji wszechświata partycypacyjnego: realne istnienie wielu, lub nawet nieskończenie wielu, światów albo akt obserwacji, który powołuje do istnienia całą materialną rzeczywistość - to ambitne pomysły uczonych, którzy są skłonni przystać na wiele, by w wyjaśnianiu „kosmicznych zbiegów okoliczności” nie odwoływać się do Boga, stwarzającego wszechświat przyjazny dla człowieka. Warto w tym kontekście zauważyć, że okoliczność ta rzuca interesujące światło na teistyczną interpretację zasady antropicznej. Przy wszystkich różnicach metodologicznych pomiędzy podejściem naukowym i teologicznym, interpretacja ta wydaje się dostarczać wyjaśnienia o porównywalnej „mocy heurystycznej" - choć jego charakter jest inny niż w przypadku hipotez czysto naukowych. Religijna wiara w Boga, powołującego do istnienia wszechświat sprzyjający życiu, co do zasady niewiele różni się bowiem od filozoficznej wiary ${ }^{45} \mathrm{w}$ realne istnienie innych światów albo w sprawczą moc aktu obserwacji, dzięki któremu uzyskuje realne istnienie cały kosmos. Który z tych dwóch „rodzajów” wiary jest bardziej racjonalny i lepiej uzasadniony? Odpowiedź na tego rodzaju pytanie z oczywistych względów zależy od światopoglądu tego, kto odpowiedzi udziela, ale w kontekście przywołanych w tym artykule

45 W obydwu tych przypadkach wiara polega na akceptowaniu jakiejś prawdy bez możliwości jej empirycznego potwierdzenia. 
argumentów staje się jasne to, że wiara religijna wcale nie musi w tym przypadku przegrywać $z$ wiarą filozoficzną.

Teistyczna interpretacja zasady antropicznej wyznacza ważny epizod nowożytnej historii teologicznych poszukiwań dotyczących objawienia naturalnego i kosmologicznych „dowodów” na obecność Boga. W nowym świetle pozwala bowiem zobaczyć stary argument dotyczący uporządkowania przyrody, który świadczy o stwórczym zamyśle Boga powołującego do istnienia racjonalny wszechświat. Naukowy kontekst, w którym toczy się obecnie dyskusja nad wyjaśnieniem „kosmicznych zbiegów okoliczności” szczęśliwie sprzyjających ewolucji życia i obecności we wszechświecie rozumnego obserwatora, z oczywistych względów nie zmienia charakteru interpretacji teistycznej - nie staje się ona naukowym dowodem przez to, że przesłanki wykorzystywanego w niej rozumowania zaczerpnięte są $z$ kosmologii i innych nauk empirycznych. Jest to nadal argumentacja o charakterze filozoficzno-teologicznym, która - podobnie jak inne „dowody” kosmologiczne rozpatrywane w teologii naturalnej-zostanie zignorowana przez uczonych poszukujących „naturalnego” wyjaśnienia antropicznych koincydencji. Dla tych jednak, którzy wierzą w Boga powołującego do istnienia wszechświat i działającego w nim za pośrednictwem praw przyrody, zasada antropiczna może stanowić ciekawy argument przemawiający za racjonalnością światopoglądu religijnego.

\section{BIBLIOGRAFIA}

Ayala F.J., Dar Karola Darwina dla nauki i teologii, tłum. z ang. P. Dawidowicz, Wydawnictwo UW, Warszawa 2009.

Barr S.M., Fizyka wspótczesna a wiara w Boga, tłum. z ang. A. Molek, Techtra, Wrocław 2005. 
Barrow J.D., Tipler F., The Anthropic Cosmological Principle, Oxford University Press, New York 1986.

Behe M.J., Darwin's Black Box. The Biochemical Challenge to Evolution, The Free Press, New York 1996.

Carr B.J., On the Origin, Evolution and Purpose of the Physical Universe, Irish Astronomical Journal 15(1982)3, 237-253.

Carter B., Anthropic Principle in Cosmology, arXiv:gr-qc/0606117.

Carter B., Large Number Coincidences and the Anthropic Principle in Cosmology, w: Confrontation of Cosmological Theories with Observational Data, red. M.S. Longair, Reidel Publishing Company, Dordrecht 1974, 291-298.

Carter B., The anthropic principle and its implications for biological evolution, Philosophical Transactions of the Royal Society A310(1983), 347-363.

Coleman S., Fine-Tuning and Probability: Does the Universe Require Explanation?, Sophia 40(2001)1, 7-15.

Conway Morris S., Life's Solution: Inevitable Humans in a Lonely Universe, Cambridge University Press, Cambridge 2003.

Davies P., Kosmiczna wygrana. Dlaczego wszechświat sprzyja życiu?, tłum. z ang. B. Bieniok, E.L. Łokas, Prószyński i S-ka, Warszawa 2008, 284.

Davies P., The Accidental Universe, Cambridge University Press, Cambridge 1993.

Davies P., Zasada antropiczna, Postępy Fizyki 37(1986)3, 215-249.

Davis J.J., The Design Argument, Cosmic "Fine-Tuning" and the Athropic Principle, Philosophy of Religion 22(1987), 139-150.

Dembski W.A., Intelligent Design: The Bridge Between Science and Theology, Intervarsity Press, Downers Grove 1999.

Dicke R.H., Dirac's Cosmology and Mach's Principle, Nature 192(1961), 440-441.

Dicke R.H., Gravitation and the Universe, American Philosophical Society, Philadelphia 1970.

Dirac P.A.M., Cosmological constants, Nature 139(1937), 323.

Drees W.B., Czy istnieja dziury, w których dziata Bóg?, w: Stwórca-wszechsiwiatcztowiek, red. M. Heller, T. Sierotowicz, t. I, Biblos, Tarnów 2006, 216-235.

Eddington A.S., Preliminary note on the masses of the electron, the proton and the universe, Proceedings of the Cambridge Philosophical Society 27(1931), 15-19.

Edwards D., Bóg ewolucji. Teologia trynitarna, tłum. z ang. E. Kwiatek, Copernicus Center Press, Kraków 2016.

Edwards D., Jak działa Bóg?, tłum. z ang. M. Chojnacki, WAM, Kraków 2013.

Ellis G.F.R., The Theology and the Anthropic Principle, w: Quantum Cosmology and the Laws of Nature: Scientific Perspectives on Divine Action, red. R.J. Russell, 
N.C. Murphy, Ch.J. Isham, Vatican Observatory and CTNS, Vatican City State - Berkeley 1996, 367-405.

Everett H., 'Relative state' formulation of quantum mechanics, Reviews of Modern Physics 29(1957)3, 454-462.

Gribbin J., Rees M., Kosmiczne zbiegi okoliczności. Ciemna materia, ludzkość i antropiczna kosmologia, tłum. z ang. P. Amsterdamski, Cyklady, Warszawa 1996.

Harris E.E., Cosmos and Anthropos. A Philosophical Interpretation of the Anthropic Cosmological Principle, Prometheus Books, New Jersey - London 1991.

Heller M., Filozofia przypadku. Kosmiczna fuga z preludium i coda, Copernicus Center Press, Kraków 2011.

Klimek Z., Koincydencje dużych liczb kosmologii i mikrofizyki, Postępy Astronomii 24(1976)4, 223-233.

Leslie J., Przejawy delikatnego dostrojenia, tłum. z ang. W. Maciejewski, Zagadnienia Filozoficzne w Nauce 16(1994), 27-62.

Pabjan T., Anatomia konfliktu. Pomiędzy nowym ateizmem a teologiq nauki, Copernicus Center Press, Kraków 2016.

Pabjan T., Argument teleologiczny, w: Przerwodnik po flozofii religii. Nurtanalityczny, red. J. Salamon, WAM, Kraków 2016, 255-269.

Pabjan T., Teoria wielu światów - nauka czy flozofia?, Filozofia Nauki 63-64(2008), 141-154.

Penrose R., Droga do rzeczywistości. Wyczerpujacy przewodnik po prawach rzadzacych wszechświatem, tłum. z ang. J. Przystawa, Prószyński i S-ka, Warszawa 2006.

Penrose R., Makroświat, mikroświat i ludzki umyst, tłum. z ang. P. Amsterdamski, Prószyński i S-ka, Warszawa 1997.

Polkinghorne J., Prawa natury i prawa fizyki, w: Stwórca-Wszechświat-cztowiek, red. M. Heller, T. Sierotowicz, t. I, Biblos, Tarnów 2006, 200-215.

Russell R.J., Boże dziatanie w świecie, w: Stwórca-wszechświat-cztowiek, red. M. Heller, T. Sierotowicz, t. I, Biblos, Tarnów 2006, 91-104.

Stoeger W.R., The Immanent Directionality of the Evolutionary Process, and Its Relationship to Theology, w: Evolutionary and Molecular Biology: Scientific Perspectives on Divine Action, red. R.J. Russell, W.R. Stoeger, F.J. Ayala, Vatican Observatory and CTNS, Vatican City State - Berkeley 1998, 163-190.

Turek J., Dlaczego wszechświat jest tak duzy, jak jest?, w: Filozoficzne i naukowo-przyrodnicze elementy obrazu świata, red. G. Bugajak, A. Latawiec, t. 3, Wydawnictwo UKSW, Warszawa 2001, 132-143.

Turek J., Kosmiczne koincydencje. Proponowane wyjaśnienia, Wydawnictwo KUL, Lublin 2014. 
Wheeler J.A., Genesis and Observership, w: Foundational Problem in Special Sciences, red. R.E. Butts, J. Hintikka, Reidel Publishing Company, Dordrecht 1977, 3-33.

Życiński J., Bóg i erwolucja. Podstawowe pytania ewolucjonizmu chrześcijańskiego, Towarzystwo Naukowe KUL, Lublin 2002.

Życiński J., The Anthropic Principle and the Teleological Interpretation of Nature, Reviev of Metaphysics 41(1987), 317-333.

\title{
SOME REMARKS ON THE THEISTIC INTERPRETATION OF THE ANTHROPIC PRINCIPLE
}

\begin{abstract}
This article attempts to answer the question of the relevance of the anthropic principle for theological arguments for the existence of God. The anthropic principle focuses on the subtle "fine-tuning" of the laws of nature and cosmological parameters, without which man could not have appeared in the universe. It seems therefore that the universe exists for a certain purpose, which is the "production" of rational observers. Because of its teleological character the anthropic principle is susceptible to theological interpretation, which assumes that God brings into existence a universe made for man. In this approach the Creator appears as the designer of the universe, albeit his design is confined exclusively to the laws of nature. This is why such an interpretation is essentially different from the so-called theory of intelligent design. This paper defends the thesis that the anthropic principle is an interesting argument - but not a scientific proof - for the rationality of religious faith in God as the creator of the universe.
\end{abstract}

Keywords: anthropic principle, cosmological coincidences, subtle fine-tuning, cosmological "proof"

TADeusz Pabjan

tadeusz.pabjan@upjp2.edu.pl

Uniwersytet Papieski Jana Pawła II w Krakowie, Wydział Teologiczny sekcja w Tarnowie

Piłsudskiego 6, 33-100 Tarnów

DOI: 10.21697/spch.2019.55.1.04 